\title{
Some Dialogue Not Yet Happened
}

\section{A Response to Michael A. Peters, "1oo Years of Dewey in China, 1919-1921:}

\section{A Reassessment"}

\author{
Huajun Zhang \\ Associate Professor, Faculty of Education, Beijing Normal University, \\ PR China \\ zhanghj@bnu.edu.cn
}

\begin{abstract}
Michael Peters' article "10o Years of Dewey in China, 1919-1921: A Reassessment" mainly focused on the political and ideological position of Dewey and concluded that Dewey did little to Chinese modern transition. To respond to Peters' article, I pointed out that Dewey's religious and aesthetic aspects of experience in his later works were largely ignored and how this idea of experience could have possible dialogue with the rich heritage of Chinese Confucianism tradition. I further made an example from the Chinese Confucian scholar Liang Shuming's review article on Dewey's book Democracy and Education, to indicate these two schools of thoughts could more contribution to thinking about the modern challenge from each society.
\end{abstract}

\section{Keywords}

pragmatism - Confucianism - dialogue

Michael Peters' article "100 Years of Dewey in China, 1919-1921: A Reassessment" mainly reviewed the historical episode of Dewey's visit of China a hundred years ago and critically commented on Dewey's view of China during the turmoil and transitional period of Chinese history. Peters basically relied on two monographs as the main resource related to this history of Dewey's visit of China to construct his points of view. One is Letters from China and Japan, co-authored by Dewey and his wife Alice Dewey and the other is the series of lectures Dewey delivered at Peking University during his visit of China (Dewey, 2015). In the article, he paid particular attention on Dewey's political/ideological position of American style of democracy and its invalidity 
to Chinese modern transition, which was actually realized by Marxist/Maoist revolution nationwide. Peters claimed that Dewey actually held a Eurocentric perspective when he made comments on the Chinese historical events he witnessed, mainly the May 4th student movement. Thus, though Dewey's lectures were eagerly received by Chinese intellectuals, especially the liberal ones, his philosophy of experience and his political proposal on social construction were not well received by the Chinese audience. One reason is due to the mis-translation/mis-interpretation of his lectures by his most important Chinese disciple Hu Shi. Peters concluded that even though "Dewey detects the "Chinese difference" he did not have enough detailed understanding of Chinese history and philosophy to give it a definite form."

Basically, I agreed with Peters in most part of his reassessment of Dewey's visit of China during 1919-1921, the very critical years in China's modern transition. Also, I agreed that Dewey's philosophy and his political ideas on social reform were not well received by Chinese audience. Thus, to evaluate the relevance of his thoughts to China's modern transition is difficult and always leaves some space for further exploring. In Peters' paper, he focused much on the difference and similarity between Dewey's pragmatism and Marxism, the later no doubt is the most critical thought for the modern China. However, Peters did not mention another thought which is also critical in China's modernization, the Confucianism culture. In the following part, I will try to address this episode of Dewey's encounter with China from a slightly different perspective, by reviewing a so-called traditionalist's view on Dewey's thoughts and relating it to Dewey's focus on the aesthetic-religious aspects of experience in his later works, which is often ignored in the study of Dewey's thoughts of education. In the following paragraphs, I would refer to the so-called "last Confucian" Liang Shuming and his critical point of view on Dewey's philosophy of education.

Because of Dewey's close relationship with his ex-Columbia Chinese students, such as Hu Shi and Jiang Menglin, who were considered as liberalists, he did not have much contact with the rivals of the liberalists, who were labeled as "traditionalists". In the context where the traditional culture was blamed as the main barrier for China's modernization, Liang Shuming's faith in Confucianism culture was often criticized and marginalized. However, in my view, his thoughts could be well complemented with Dewey's, which is far beyond the points of view labelled as instrumentalist rationality. Furthermore, Liang's comments on Dewey's thoughts predicted Dewey's evolutionary idea in his later works. Even though there were no records of Dewey and Liang's faceto-face meeting during the period of Dewey's visit to China, I would suggest that Liang's comments on Dewey's Democracy and Education actually initiated a deep dialogue between these two thinkers. We could not know whether 
Dewey read or heard about Liang's comments, but Dewey's development of his thoughts on experience in his later works, mainly Art as Experience and Nature and Experience, responded to Liang's critical comments, to some extent.

Basically, Liang considered the essential idea of Dewey's philosophy is his idea on life - that human life is unique because it has the capability of learning new things and actively connecting with anything in the universe. Liang considered that Dewey's understanding of life is highly consistent with Chinese Confucianism (Liang, 2012). Liang delivered this lecture on Dewey's Democracy and Education during the period when he led the rural reconstruction movement in Shandong Province in 1934. Liang's basic understanding of Dewey's philosophy is quite different from Dewey's disciple Hu Shi, who emphasized Dewey's scientific method of intelligence and how the thinking experiments could be applied to the social reforms. It is also quite different from Peters' perspective in his article, which focused more on Dewey's social and political philosophy of democracy and its brief comparison with Marxism.

Interestingly, Dewey did not clearly elaborate his philosophy of experience from the perspective of life as the living things until in his later work Art as Experience (1934). Undoubtedly Liang had not read this book when he commented on Dewey's Democracy and Education, which was published in 1916. It seems that Liang foresaw Dewey's later development of his thoughts, which focused on the much more delicate description of the inner movement of experience than he did in his middle works such as Democracy and Education. We could see that Dewey paid special attention to aesthetic and religious experience in his later works. Indeed, even though many intellectuals, Chinese or international, who were interested in Dewey's thoughts celebrated Dewey's pragmatism rationality or the called scientific method of intelligence, Liang sharply pointed out that the value of Dewey's thoughts relied on his understanding of connectivity and creativity of life in the whole universe. Liang mentioned that the spirit of democracy in Dewey's thoughts is the potentiality and creativity of the associate life which led to a moral thus democratic society (Liang, 2012).

From the discussion of Liang's comments on Dewey, we could see that Liang did un-intentionally initiate some dialogue which did not happen in reality but lasted in a very deep way. Both Liang and Dewey's faith in the potentiality of the human life for an expanded individuality and associated way of living together led to a vision of cosmopolitanism, a universe without various barriers and categories to separate the living things, the life. In the contemporary world full of splitting and conflicts often in the names of multiculturalism or liberal democracy, their common faith is worthy of reconsideration and more dialogue on life and experience might be needed to face the challenge of the contemporary globalized society. 


\section{References}

Dewey, Alice \& Dewey, John (1920) Letters from China and Japan. New York: E.P. Dutton \& Company.

Dewey, John (2015) Lectures in Social and Political Philosophy, 1919-21. Symposia. John Dewey's Lectures in Social and Political Philosophy (China), European Journal of Pragmatism and American Philosophy, VII (2) pp. 7-45.

Dewey, John (1934) Art as Experience. New York: Minton, Balch \& Company.

Liang, Shuming (1934) Du Wei Jiao Yu Zhe Xue Zhi Gen Ben Guan Nian (The basic idea of John Dewey's philosophy of education). Reprinted as a chapter in Liang Shuming (2012) Education and Life: The Collection of Liang Shuming's Work on Education. Beijing: Dang Dai Zhong Guo Press. 